\title{
Article
}

\section{The development and decline of Morecambe in the nineteenth and twentieth centuries: a resort caught in the tide}

\author{
Jarratt, David \\ Available at http://clok.uclan.ac.uk/29234/ \\ Jarratt, David ORCID: 0000-0002-7244-428X (2019) The development and \\ decline of Morecambe in the nineteenth and twentieth centuries: a resort \\ caught in the tide. Journal of Tourism History, 11 (3). pp. 263-283. ISSN 1755- \\ $182 X$
}

It is advisable to refer to the publisher's version if you intend to cite from the work. http://dx.doi.org/10.1080/1755182X.2019.1643932

For more information about UCLan's research in this area go to http://www.uclan.ac.uk/researchgroups/ and search for <name of research Group>.

For information about Research generally at UCLan please go to http://www.uclan.ac.uk/research/

All outputs in CLoK are protected by Intellectual Property Rights law, including Copyright law. Copyright, IPR and Moral Rights for the works on this site are retained by the individual authors and/or other copyright owners. Terms and conditions for use of this material are defined in the policies page.

\section{CLoK}

Central Lancashire online Knowledge www.clok.uclan.ac.uk

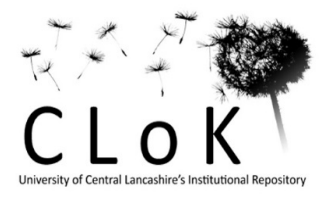




\section{The development and decline of Morecambe in the 19th and 20th centuries:}

\section{A resort caught in the tide.}

\section{David Jarratt}

Lancashire School of Business and Enterprise, University of Central Lancashire (UCLan), Preston, Lancashire, PR1 2HE, UK.

ORCID: https://orcid.org/0000-0002-7244-428X

E-mail: DJarratt@uclan.ac.uk

Twitter: @DavidJarratt1

David Jarratt (Ph.D.) is a Senior Lecturer in Tourism within the Lancashire School of Business and Enterprise (LSBE), UCLan, UK. His research interests include coastal resorts, sense of place, wellness, nostalgia, heritage tourism and tourism history. Amongst other things, he has written about the visitor's sense of place at traditional seaside resorts, or 'seasideness'. 


\section{Introduction}

The popular account of the rise and fall of British seaside resorts is a nostalgia-fuelled story of decline and deterioration in which the resorts struggle to function as pleasure zones because, since the 1960s, they have been superseded by Mediterranean package holidays. This has been supported by countless media observers over the years. ${ }^{1}$ However, this narrative glosses over many complexities and does not account for local variance and circumstances. In contrast, this article reflects upon the variety of macro and micro factors, at a global and local level, which characterise resort histories and help shed light on why 'one resort prospers and another is in crisis'. ${ }^{2}$ In order to do this, the focus is on one resort - Morecambe, a medium sized resort on the North West coast of England. It makes a fascinating case because its decline was so severe and it is a timely choice, as Morecambe now appears to be making some headway with its attempts at regeneration. Mass tourism may yet make a return to a place which lost most of its touristic infrastructure and became the subject of comedy. The history of any town is multilayered, but this article purposively focusses on tourism (i.e. the visitor economy), the industry which brought the resort into being and, although depleted, remains vital to its economy. It also concentrates on the 19th and 20th centuries, which saw the establishment and erosion of mass tourism in Morecambe.

In the late 20th century relatively few historians concerned themselves with mass consumption by the working classes and, in particular, seaside resorts. However seaside

\footnotetext{
1John K.Walton, The British seaside: Holidays and resorts in the twentieth century (Manchester: Manchester University Press, 2000), 14 . Here Walton outlines this phenomenon but for a very recent example (8th August 2018) see Channel 5 news 'Real Coasts: are seaside towns like Morecambe getting left behind?', https://www.youtube.com/watch?v=cuVv w-1z3k\&mc cid=e88956ceee\&mc eid=0c601b55e0. For a typical example (from 2016) see, The Mail Online, 'All Washed Up: Haunting pictures show how Britain's most loved seaside towns have declined over the last 30 years', http://www.dailymail.co.uk/news/article-4004884/Haunting-picturesdecline-Britain-s-seaside-towns.html.

${ }^{2}$ Allan Williams and Gareth Shaw, 'Riding the big dipper: The rise and decline of the British Seaside Resort in the 20th Century', in The Rise and Fall of British Coastal Resorts: Cultural and Economic Perspectives, ed. Gareth Shaw and Allan Williams (London: Mansell, 1997), 13. Also see Sheela Agarwal, 'Restructuring seaside Tourism: The Resort Lifecycle', Annals of Tourism Research, no. 29 (2002): 25-55.
} 
histories have been relatively well researched more recently. ${ }^{3}$ Indeed, an increasingly comprehensive picture of seaside history has developed. The retired seaside historian John Walton has left a significant body of work and English Heritage (now Historic England) have been cataloguing the rich history and heritage of the coast. ${ }^{4}$

Before considering Morecambe, it is useful to briefly consider the factors that enabled the growth of mass tourism more generally. Seaside tourism began as an appurtenance to the spa season; the earliest resorts of Scarborough, Brighton and Margate had recognisable bathing seasons in the $1730 \mathrm{~s} .{ }^{5}$ For years to follow the seaside facilitated the pursuit of health and fashion. These early days were socially exclusive but as an industrial society and as the middle classes developed, the social spectrum of the seaside widened. In the same way that the inland spas had witnessed royal patronage and upper-class exclusivity eventually make way for 'lower' social orders, so the appeal of the seaside environment worked its way 'down' through society. Health would remain crucial to a widening seaside appeal, although by the late 19th century the emphasis was on sea air, sunshine and climate rather than bathing; furthermore popular entertainment and the carnivalesque were a more prominent part of the experience. ${ }^{6}$

Walton argues that five conditions had to be met for the English Seaside to attract working-class residential tourists and so ensure the development of the seaside resort. ${ }^{7}$ These were:

\footnotetext{
${ }^{3}$ Gareth Shaw and Sheela Agarwal, 'The Development and Management of Coastal Resorts: A Global Perspective', in Managing Coastal Tourism Resorts: A Global Perspective, ed. Agarwal and Shaw (Bristol: Multilingual Matters, 2007), 2.

${ }^{4}$ For instance - Walton, The British Seaside; Allan Brodie, The Seafront (Swindon: Historic England, 2018).

5John K. Walton, The English Seaside Resort: A Social History 1750-1914 (Leicester: Leicester University Press, 1983), chapter 1.

'John Beckerson and John K.Walton, 'Selling Air: Marketing the Intangible at British Resorts', in Histories of Tourism: Representation, Identity and Conflict, ed. John K. Walton (Clevedon: Channel View, 2005), 55-70; Rob Shields, 'Ritual Pleasures of a Seaside Resort: Liminality, Carnivalesque, and Dirty Weekends', in Places on the Margin: Alternative geographies of modernity (London: Routledge, 1991), 89.

7John K. Walton. 'The Demand for working-class seaside holidays in Victorian England', Economic History Review, 34 (1981): 249-265.
} 
1) Cheap and effective transport to a suitable coastline. The growth of the railway system in the mid-19th century in particular.

2) The working classes had to have sufficient income to afford a holiday in times when holidays were not paid

3) The seaside visitors would need several days holiday back-to-back in the summer.

4) The resorts had to have sufficient facilities; supply must meet demand.

5) The labour force must choose to spend their hard earned saved income at the seaside; the resorts needed to be attractive.

Variables in resort development were numerous and included industrialisation in the hinterland, land ownership, local government, entrepreneurial activity, topography and transport. Therefore one must consider resorts on a case by case basis to understand their growth and also their decline.

Yet, the Lancastrian resort of Morecambe has received little attention from historians. One exception comes from a local historian; Roger Bingham describes the noteworthy reversal of fortunes experienced by the resort ${ }^{8} \mathrm{He}$ offers an introduction to Morecambe's flow and ebb but does not focus on the reasons behind these shifts and the subsequent decline, as this article sets out to do.

\section{The establishment of mass tourism in Morecambe}

The area now known as Morecambe was subject to Celtic settlement and was subsequently referred to in Roman records. Over the centuries, small fishing villages and farmsteads developed in this area but, prior to the 19th century, this area would only be visited by travellers wishing to cross the large tidal bay that characterizes the area. ${ }^{9}$ However, by the early $1800 \mathrm{~s}$

\footnotetext{
${ }^{8}$ Roger Bingham, Lost Resort? The Flow and Ebb of Morecambe (Milnthorpe, Cumbria: Cicerone, 1990).

${ }^{9}$ Cuthbert Woods, The Oversands Route between Lancaster \& Ulverston (CWAAS, 1935),

https://www.hslc.org.uk/wp-content/uploads/2017/06/87-2-Woods.pdf
} 
people began to visit 'Morecambe', as it was later to be called, for its own sake. Its initial development as a resort is largely typical; it was one of several Lancashire watering places. ${ }^{10}$ However, there was no single landowner with the ability to plan the development and control social tone as occurred in some Lancastrian resorts, notably Southport and Lytham. In addition, it was relatively late in developing as a resort. For example, Blackpool was already a popular resort as Morecambe called itself a 'watering place' for the first time; Blackpool 'was beginning to flourish' in the 1780 s some forty years before Morecambe began to do so. ${ }^{11}$

The area started to become busier in the 1810 s and in the 1820 s steamers visited for the first time. In this decade, sea bathing was becoming increasingly popular in the villages that would later become known as Morecambe, of which Poulton-le-Sands was the largest. 1829 was a key date for the development of tourism in the resort, as it was the first year of a popular annual regatta event; Poulton-le-Sands was now clearly established as a tourist destination. The tourists were likely to be of high social standing in comparison to the masses that were to follow in subsequent years. For instance, John Ruskin recovered from illness at the resort in 1886 whilst hotels adverting in the late 1820 s and 1830 s were aimed at 'Genteel Families'. ${ }^{12}$ These decades were when the resort first promoted itself as a healthy watering place. The name change of the conurbation took place in 1889 although this fusion of expanding villages had been referred to as Morecambe since the arrival of the railway which terminated at 'Morecambe' station; this name was taken from the great bay on which the town sits. ${ }^{13}$

Until the arrival of the railway, Morecambe was a minor resort in its infancy. The railway was opened at Morecambe in 1848 as part of a commercial port line that was constructed to link Heysham (the port next to Morecambe and effectively part of the resort

\footnotetext{
${ }^{10}$ William Farrer , and J. Brownbill, A History of the County of Lancaster: Volume 8 - Poulton, Bare and Torrisholme (British History, 1914), https://www.british-history.ac.uk/vch/lancs/vol8/pp64-69

${ }^{11}$ Walton, The English Seaside Resort, 15.

${ }^{12}$ Bingham, Lost Resort, 62, 77.

${ }^{13}$ Community Rail Alliance, 'A short history of the Bentham Line', https://www.communityraillancashire.co.uk/ashort-history-of-the-bentham-line/
} 
today) and West Riding in Yorkshire. The Morecambe Harbour Railway was a branch of the North Western Railway Company, which was to be taken over by The Midland Railway just over two decades later. As with all railways of this period, passenger travel was very much a secondary concern in the planning of new routes; a variety of goods, notably iron and Irish cattle were to be transported on the line which linked to the new jetties at Morecambe. ${ }^{14}$ However, the railway company was quick to recognise an opportunity and promote Morecambe as a destination. In 1850, Leeds and Bradford were connected to the line and the Midland Railway was notable for its policy of cheap fares and associated advertising, ensuring it took the popular path. ${ }^{15}$ Pleasure steamers also operated between Morecambe and Liverpool, Blackpool and other resorts. For instance, in 1855 the Arbutus began pleasure trips to Fleetwood and the Isle of Man with up to 700 people and a band on board. By 1853, Morecambe offered eighteen bathing machines to allow 'dipping'. ${ }^{16}$ The surge of numbers and development at Morecambe was clearly due to the railway connection as observed in 1914, 'The place became a popular sea-bathing resort about a century ago, and after the opening of the railway in 1848 rapidly advanced'.${ }^{17}$ Furthermore, the second half of the $19^{\text {th }}$ century was a time of growth for resorts across the country; in 1801 about $1 \%$ of the population lived in seaside resorts, but by 1871 that figure was over $4 \% .^{18}$

The 1850s and 1860s saw Morecambe develop as a destination for day-trippers. In the second half of the 19th century, Morecambe's expanding market was increasingly working class and, in this sense, it represented one of the few regional competitors to Blackpool. Nevertheless, in 1894 it attracted fewer than 8,000 visitors on August Bank Holiday Monday

\footnotetext{
${ }^{14} J o h n$ Pimlott, The Englishman's Holiday: A Social History (London: Faber and Faber, 1947); Bingham, Lost Resort, 74. Also see: Lancaster Railway Club, 'Local History', http://www.lancasterrailwayclub.co.uk/?page_id=121

${ }^{15}$ John K. Walton, Wonderlands by the Waves; A History of the Seaside Resorts of Lancashire (Preston: Lancashire County Books, 1992), 39.

${ }^{16}$ Bingham, Lost Resort, 71,81.

${ }^{17}$ William Farrer and J. Brownbill, A History of the County of Lancaster: Volume 8 - Poulton, Bare and Torrisholme (British History, 1914), https://www.british-history.ac.uk/vch/lancs/vol8/pp64-69

18 Pimlott, The Englishman's Holiday, 173.
} 
when Blackpool attracted ten times this number. ${ }^{19}$ Tourism-related statistics from the past should be treated as indicative; essentially, nobody was accurately or consistently counting visitor data until recently. ${ }^{20}$

Nevertheless, it was clear that Morecambe was now dwarfed by Blackpool, which had come to dominate the market. Blackpool was much closer to the large urban conurbations of North West England, already had an established touristic infrastructure which had developed over a longer period and had become part of a holiday-making tradition. ${ }^{21}$ This situation was set to continue, but Morecambe was successful with one market in particular. Morecambe still attracted more visitors from Yorkshire than its larger rival; the resort was known as 'Bradfordby-the Sea'. It relied on a single rail link to Yorkshire, its main market. This was to be problematic; the economic fortunes of Morecambe were to reflect those of the Bradford area, which in turn were intertwined with one industry - textiles. The railway link to Morecambe, whilst essential to growth, ensured that the resort would always be in the shadow of Blackpool, which was better served by rail. ${ }^{22}$ Yet the growth in tourism at both resorts was enabled by the railways and was to increasingly rely on the working classes.

In 1848, the original Midland Hotel opened its doors and one year later the promenade opened. In the 1860 s and even into the early 1870 s, many attractions were still 'genteel' and decidedly small scale, such as Professor Groves' exhibition of dioramic scenes in $1866 .^{23}$ However, this was about to change. The first public salt-water baths were opened in 1867 and included cheap bathing for the working classes on Saturday afternoons from 1869. In that same

\footnotetext{
${ }^{19}$ Walton, Wonderlands by the Waves, 4.

${ }^{20} \mathrm{Tim}$ Gale, 'The Problems and Dilemmas of Northern European Post-Mature Coastal Tourism Resort' in Managing Coastal Tourism Resorts: A Global Perspective, ed. Agarwal and Shaw (Bristol: Multilingual Matters, 2007), 23.

${ }^{21}$ James Walvin, Beside the Seaside (London: Penguin, 1978), 159-161; John Urry and Jonas Larsen, The Tourist Gaze 3.0 (London: Sage, 2011), 43-48.

${ }^{22} J o h n$ Grass, 'Morecambe, the people's pleasure: The Development of a holiday resort, 1880-1902' (M.A. dissertation, Lancaster University, 1972).

${ }^{23}$ Bingham, Lost Resort, 83.
} 
year, a pier was opened followed by the People's Palace or Winter Gardens in 1878 to cater to this growing market. In 1879 the Summer Gardens were opened and became one of the first places in England to use electricity. The Summer Gardens, as with many forgotten seaside attractions, failed; it could not compete with the Winter Gardens and went into liquidation in 1890. The Winter Gardens established itself as the main resort venue and famous troupes, such as the Merry Japs Vaudeville group, played there later in its history. Musical entertainment proved to be a cornerstone of Morecambe's popular appeal. Horse trams arrived in 1886 and the West End Pier, Morecambe's second, opened in $1896 .{ }^{24}$ In 1897 its predecessor, the Central Pier, gained two pavilions which were dubbed the 'Taj Mahal of the North' due to their oriental décor. ${ }^{25}$ All of these developments point to the fact that the 1870 s through to the 1890 s was a significant period in the evolution of the resort, especially in terms of tourism infrastructure.

This period saw the transition of Morecambe from an exclusive watering place to a mass tourism resort. In the second half of the $19^{\text {th }}$ century, Morecambe aspired to meet the increasing demand for accommodation but it seems that supply usually lagged well behind demand. As in many other resorts, the early days of mass tourism were marked by overcrowding. In August 1851, for example, Morecambe was so full on the weekends that visitors had to sleep in Lancaster and in mid-September that year tourists even slept on board a pleasure steamer. More guest houses were built but, in the 1890s, the resort was still full to the point of overcrowding in the high-season. ${ }^{26}$ Accurately gauging the extent of accommodation provision is challenging. According to Grass, the number of lodging houses more than tripled in the last two decades of the century and exceeded 500 by the turn of the century. ${ }^{27}$

\footnotetext{
${ }^{24}$ National Piers Society, 'Lost Piers', https://www.piers.org.uk/pier/morecambe-west-end-pier/ ${ }^{25}$ Kathryn Ferry, The British Seaside Holiday (Oxford: Shire Publications, 2009), 102.

${ }^{26}$ Christopher Widdowfield, 'The Local of Health of Poulton, Bare and Torrisholme and the Development of Morecambe, 1852-1984' (Undergraduate Dissertation, University of Lancaster, 1973), 10-11.

27 Grass, Morecambe: 'The People's Pleasure', 26.
} 
An 1899 guidebook commented on the transition of the area over the last thirty years of the century,

Poulton of the old time was a fishing village and nothing more, somewhat thickly populated with a hardy, athletic and singularly fine-looking men; buxom women, to keep them well-favoured husbands and brothers in countenance; teaming nurseries of promising children - all more or less amphibious. ${ }^{28}$ It identifies the coming of the railway as an enabler of the "wonderful influx of health-seeking humanity'. ${ }^{29}$ An earlier rival guidebook from 1889 makes similar claims; focussing on the natural beauty and health-giving properties of the environment - it reports that Morecambe's water supply 'is the best and purest' in England, the air bracing, the temperature is two degrees warmer than the South of England ('perfect for invalids') and the average life span for locals is longer than average ${ }^{30}$ Interestingly, this document seemed to be aimed at more traditional markets, extolling Morecambe's 'admirable suitability for the requirements of the middleclasses'. As such the guide might reflect the aspirations of the resort rather than the new commercial reality. In any case, both guides go on to list the various features and attractions of the resort, as discussed in this article; the 1899 guide summarises the notable additions to infrastructure,

And so Morecambe has gone and flourished, until it now boasts a multiplicity of first-rate lodging houses and shops, two markets, many handsome and commodious hotels, two pleasure piers, an excellent promenade nearly three miles in length, every convenience for sea-bathing, and above all possessing views which for breadth and beauty surpass those of any other watering places in the country ${ }^{31}$.

Unsurprisingly this document, which was written to promote the resort, does not offer any indication of the real struggle facing businesses in the 'local slump' at this time, which reflected economic concerns in the Leeds/Bradford area. ${ }^{32}$ The resort was dependent on this market and

\footnotetext{
${ }^{28}$ Johnsons Guides for the People, A new guide to Morecambe and Neighbourhood (Blackburn: Johnsons, 1899), 3. ${ }^{29}$ Ibid., 4.

${ }^{30}$ Gorton's, Official Guide to Morecambe (Morecambe: A.W. Gorton, 1889), 1-4.

${ }^{31}$ Johnsons Guides for the People, A new guide to Morecambe, 6.

${ }^{32}$ Walton, The English Seaside Resort, 178; Urry and Larsen, The Tourist Gaze 3.0., 46.
} 
Bradford's downturn in at the turn of the century impacted upon Morecambe much more than any other resort. In 1901 The Alhambra opened but it would struggle financially and soon closed. In 1898 a revolving tower was built, with ballroom and roller skating rink, but encountered various technical and financial problems and was dismantled in $1918 .{ }^{33}$ Observers had counted the number of lodging houses at 150 in 1881,513 in 1899 and 344 by $1913 .{ }^{34}$ So this post-boom slump was significant to the resort's economy and tourist infrastructure. However, Morecambe would soon recover from the economic downturn. As the resort moved into the next century, the numbers of those visiting Morecambe, and many other English resorts, would 'soar'. ${ }^{35}$ The number of middle class visitors continued to grow but increasingly it was the working classes who were associated with the boom of the inter-war and post-war periods.

\section{The height of mass tourism in Morecambe}

As suggested above, the growth of the visitor economy continued throughout the first half of the 20th century, despite the interruption of two world wars. The level of growth varied widely between resorts and it is difficult to assess accurately, but census information states that, between 1911 and 1951, Morecambe grew by an impressive 205\% to a population of 37006 . Walton points out that the medium-sized resorts working class resorts, namely, Clacton, Bridlington, Weston-Super-Mare, Ramsgate, Skegness and Morecambe, all expanded rapidly in this period. Much of the population growth in Morecambe and other seaside resorts was due to the increasing numbers of retiree settlers and commuters. ${ }^{36}$ For these resorts, boom was

\footnotetext{
${ }^{33}$ Brodie, The Seafront, 166; Chad Randl, Revolving Architecture: A history of buildings that rotate and pivot (New York, Princeton Architectural 2008), 42-45.

${ }^{34}$ Grass, 'Morecambe: The People's Pleasure', 26.

35 John K. Walton, 'The seaside resorts of England and Wales, 1900-1950: growth, diffusion and the emergence of new forms of coastal tourism' in The Rise and Fall of British Coastal Resorts: Cultural and Economic Perspectives, ed. Gareth Shaw and Allan Williams (London: Mansell, 1997), 22.

${ }^{36}$ Ibid., 27.
} 
destined to be followed by bust - more of that later. Walton points out that seaside resorts were becoming 'really distinctive demographically' in-between 1871 and $1911 .^{37}$ These trends continued and became even more apparent in the inter-war period. The population increased but it also became significantly older due to the influx of retirees. Indeed, Morecambe's inter-war population was on average the second oldest in the region. A 'large proportion' of Morecambe's population was aged between 45 and $80 .{ }^{38}$ The immigration of retirees was to be seen in other Lancastrian resorts although the overall average age was lower, suggesting that more commuters were settling in the other resorts. ${ }^{39}$ Despite this, attracting both commuters and (more successfully) retirees was a key concern to the local government, whilst Blackpool's leaders appeared to focus much more on expanding their tourism market. ${ }^{40}$ As will become clear, the association with the elderly was also problematic to the resort's image in the mid/late 20th century.

The numbers of visitors grew rapidly and underpinned the success of Morecambe, although ascertaining the exact numbers is difficult. The 1926 figure of $1,191,474$ for the season is based on rail arrivals and estimates of road arrivals. It is estimated that Blackpool attracted at least three times more visitors during this period. ${ }^{41}$ There is no doubt where the majority of these tourists came from - that is, from the towns of Lancashire and West Riding. The Midland line (to Yorkshire) was clearly still determining who visited the resort. In 1932, the Postmaster of Morecambe and Heysham provided detailed statistics regarding not only the number of postcards sent but also their destination. This provides us with a 'top ten' tourist generating towns and cities for visitors to Morecambe in 1932 and demonstrates that

\footnotetext{
37 Walton, The English Seaside Resort, 100.

${ }^{38}$ Ian Simmill, 'The development of a Lancashire Industrial Town, Morecambe, during the Inter-War Years 19191939' (MA dissertation, Lancaster University, 1993), 14.

${ }^{39}$ Harold Perkin, The Age of the Railway (London: Granada Publishing, 1970), chapter 8.

${ }^{40}$ Simmill, 'The development of a Lancashire Industrial Town', chapter 4.

${ }^{41}$ Ibid., 41-42.
} 
Morecambe was primarily a resort of Yorkshire and the North-West, but not a truly national one like Blackpool:

1) Leeds

2) Bradford

3) Manchester

4) Oldham

5) Liverpool

6) Bolton

7) Huddersfield

8) Halifax

9) Preston

10) Rochdale ${ }^{42}$

Contemporary observers were often critical of Morecambe Corporation's performance in terms of resort management, particularly in the 1920s. Criticisms included high rates (local property tax) for residents, stopping the Carnival, the lack of venues, demolishing the derelict but historic Poulton Hall, their refusal to build a Greyhound track and ill-judged spending on a ring road and town hall. The local press considered the Corporation to be failing to provide the facilities necessary to compete with rivals. ${ }^{43}$ In comparison to other resorts Morecambe did very little to improve the physical appearance of the town and most successful developments in this period were from the private sector. The national economic situation improved in the 1930s and criticism of the Corporation lessened. Notable attractions from this era included the nationally recognised Morecambe Music Festival and a fairground with a big dipper. The illuminations were also popular and became increasingly elaborate through the 1930s. The Art

\footnotetext{
${ }^{42}$ Ibid., 40.

${ }^{43}$ Ibid, chapter 4.
} 
Deco / Seaside Moderne Midland Hotel opened in 1933 to replace its predecessor, which burnt down, and successfully attracted the rich and famous as a destination hotel. This was one of the first Modernist buildings erected at the seaside. ${ }^{44}$ Indeed a number of Art Deco buildings were erected during this period in Morecambe, some of which survive today. ${ }^{45}$ Most notable amongst the modernist structures that did not survive, was the grand 'Super Swimming Stadium' which opened in 1936. This once popular attraction was reputed to be the largest lido in Europe. Its popular appeal did not just lie in swimming, as it became a venue for aquatic events and a variety of other shows. ${ }^{46}$

The Second World War did, of course, interrupt the continued expansion of leisure tourism. Activity by the Corporation in the post-war period seemed modest, with plans for a new library and a doomed plan to turn Morecambe into a major port for seaplanes, heading the short list of efforts by the public sector. The private sector had some projects around this time though. For example, the remaining Tower Complex, minus the tower, was reinvented as the Gaumont in 1949. ${ }^{47}$ The 1940s saw investment in Morecambe Pleasure Park, later Frontier Land, by the Thompsons. ${ }^{48}$ Indeed, the late 1940s and 1950s saw Morecambe enter into an intense but short-lived period of post-war prosperity.

Bingham marks Morecambe's height of popularity as the 'switch on' night of 1949 which attracted well over 100,000 visitors. The 1950 illuminations, opened by George Formby, approached these visitor numbers too but they were never to be repeated or bettered. The lights

\footnotetext{
${ }^{44}$ Barry Guise and Pam Brook, The Midland Hotel: Morecambe's White Hope (Lancaster: Carnegie Publishing, 2008); Brodie, The Seafront, 193.

${ }^{45} \mathrm{~A}$ good summary of the surviving Art deco buildings in the area - Art Deco \& Art Nouveau Buildings in Morecambe \& Heysham, The Lakeland Rambler Blog, posted $24^{\text {th }}$ June 2016, https://lakelandrambler.wordpress.com/2016/06/24/art-deco-art-nouveau-trail-in-morecambe-heyshamtwenty-buildings-blog/

${ }^{46}$ The Twentieth Century Society, 'Super Swimming Stadium, Morecambe', https://c20society.org.uk/lostmodern/super-swimming-stadium-morecambe/; Lost Lidos, 'Morecambe - Super Swimming Stadium 1936', https://www.lostlidos.co.uk/1999/07/29/morecambe-swim-stadium/

${ }^{47}$ Bingham, Lost Resort, chapter 5.

${ }^{48}$ The Visitor, 'End of the Ride for Frontierland', 22/08/07, https://www.thevisitor.co.uk/news/end-of-the-ridefor-frontierland-1-1207493.
} 
were at their best in this period but still did not match those of Blackpool. ${ }^{49}$ The only event in the resort to rival the popular appeal of the illuminations was the Miss Great Britain competition which began in 1945 and from 1956 to 1989 was held at the swimming stadium, attracting national press coverage ${ }^{50}$ Other forms of entertainment took place in the numerous cinemas, theatres and pavilions - Morecambe was known for its entertainment. The old Pierrot tradition thrived, and variety and talent shows proved very popular. Various famous acts came and went and, in these early post-war years, talented local entertainers emerged such as Eric Morecambe and Thora Hird.

At first glance, it may seem paradoxical but the era of post-war rationing and austerity led to something of a visitor boom for seaside resorts. Ward and Hardy explain:

The end of the war brought a holiday explosion among the British. Not only had the pre-war holidays with pay legislation come into effect, so that five out of six earners had holiday pay, but the war had brought full employment for the first time, with a huge increase in the size of the workforce. It had also lowered the average age of marriage and had brought a baby boom. A new generation of young families was conscious that their children had never seen the sea. ${ }^{51}$

The demobilization of half a million men phased over a number of years will have also fed into this trend. Walvin also comments on this apparently paradoxical situation - fuelled by people's determination to have fun,

If we concentrate on the seaside towns in the first decade after the Second World War, it seems difficult to believe that the country was in the grip of serious economic troubles. Record crowds, the volume of money flowing into the resorts, growing competition road and rail and the rapid revival of seaside entertainments - all suggest a prospering economy. The real picture was of course quite different, and it seems that, as in the case of cinema and football, the resorts thrived in inverse proportion to national

\footnotetext{
${ }^{49}$ Bingham, The Lost Resort, 258-261.

${ }^{50}$ Miss Great Britain, 'History of Miss Great Britain', www.missgreatbritain.co.uk/history.

${ }^{51}$ Colin Ward and Dennis Hardy, Goodnight Campers! History of the British Holiday Camp (London: Mansell

Publishing, 1986), 74.
} 
prosperity. The harsher the times, the more intent people seemed to have been on enjoyment, and the more determined to spend their spare money on having a good time. ${ }^{52}$

The challenging economic situation appeared to correlate with a boom for seaside resorts. Unfortunately for the resorts, this also appeared to work in reverse; for it was the following era of relative prosperity that saw troubling signs for seaside resorts. The following section introduces and explains these issues; later the particularly dramatic case of Morecambe is explored in more detail.

\section{The decline of mass tourism in English resorts}

The post-war boom in visitor numbers marked the height of popularity for many resorts and, by the late 1950 s, there were increasingly clear signs that the traditional resorts were starting to lose their middle-class custom. In the same year, the shortcomings of low-grade traditional seaside accommodation and changes in customer expectations were pointed out by The British Tourist and Holiday Board; they linked increased prosperity with rising expectations of visitors and identified a slackening in demand in relatively low grade accommodation..$^{53}$ Against this backdrop, the mid-20th century saw a dramatic change in national holiday habits. Climate had been significant to resorts and holidaymakers for years - weather and hours of sunshine in different English resorts were reported and discussed. ${ }^{54}$ However, changes to transportation in post-war decades enabled British tourists to leave home to enjoy sun, sea and sand in the Mediterranean.

By the 1960s it was becoming clear that the future of mass-market leisure travel lay in the international movement from North to South. ${ }^{55}$ Yet the international travel market of the 1960s and early 1970s was dominated by the upper and middle classes in Britain - this was not

\footnotetext{
${ }^{52}$ Walvin, Beside the Seaside, 131.

53 British Tourist and Holidays Board, Survey of Holiday Accommodation (London: B.T.H.B., 1949).

${ }^{54}$ Ibid.

${ }^{55}$ Chris Holloway and Claire Humphries, The Business of Tourism (Cambridge: Pearson, 2016), 51-71.
} 
a period of cheap foreign travel by modern standards. Indeed, the peak of domestic holidays taken in Britain was in1974. From 1978 onwards, however, the number of holidays abroad increased significantly. In 1979, the number of holidays taken abroad rose above 10 million for the first time and the number of domestic holidays fell by half a million. However, the early 1980s was the first time many of the working classes could afford annual package holidays to Greece, Portugal or Spain. ${ }^{56}$ The same decade saw Blackpool's first a notable drop in tourist numbers and Morecambe entered its darkest period.

Many working-class seaside resorts, like Morecambe, saw a notable decline before overseas package holidays became commonplace for their clientele. Visitors were going elsewhere in the UK; domestic competition from other tourist destinations and leisure activities became much more significant since the leisure boom of the 1960s. One particular challenge for these seaside resorts, located at the end of a railway line, was the impending age of motor car which offered more flexibility and opened up a broader range of leisure opportunities ${ }^{57}$ Not least amongst these was rural tourism and camping/caravanning. Meanwhile, the South-West of England started to develop into the UK's most popular seaside destination. ${ }^{58}$ This region did not have to carry the 'baggage' of the older resorts. Also, the industrial cities, from which the population once wanted to escape, became de-industrialised and in time developed their own tourism and leisure economies that have come to surpass those of most seaside resorts. The growth in competition affected medium-sized and 'working class' resorts more significantly than the larger and/or more upmarket resorts, which still held some popular appeal.

Cultural shifts can also partially explain the challenges facing the seaside. John Urry accepts the role of competition and the resort cycle that leave resorts looking tired but focuses

\footnotetext{
${ }^{56}$ Walton, The British Seaside, 66-70.

${ }^{57}$ Chris Cooper, 'Parameters and indicators of the decline of the British seaside resort', in The Rise and Fall of British Coastal Resorts: Cultural and Economic Perspectives, ed. Shaw and Williams (London: Mansell, 1997), $77-$ 102; Holloway and Humphries, The Business of Tourism, 20-49.

${ }^{58}$ Julian Demetriadi, 'The golden years: English seaside resorts 1950-1974', in The Rise and Fall of British Coastal Resorts: Cultural and Economic Perspectives, ed. Shaw and Williams (London: Mansell, 1997), 49-79.
} 
on the fact that these resorts were no longer fashionable and did not represent good taste. He explains this shift through culture wars, maintaining that the service (managerial and professional) class have imposed their values and beliefs on society. These beliefs include the veneration of culture, nature and authentic experiences. This imposition naturally led to the denigration of the seaside resorts, especially the working class ones, which are not perceived to reflect these values. ${ }^{59}$ Morgan and Pritchard also stress the significance of class at the seaside and write about the hierarchy of destinations and the struggle between different social groups. They comment that 'tourism is a cultural arena in which hegemonic ideas of superiority and inferiority are continuously played out' and conclude by predicting that 'social tone is likely to remain a prime shaper of tourism development for the foreseeable future' ${ }^{60}$ Shields adopts a different stance, in explaining the loss of appeal - the seaside resorts lost some of the Carnivalesque qualities that made them distinctive places of liberation, freedom and fun. ${ }^{61}$ Gale established a link between the cultural turn from modernism to postmodernism and the decline of tourism in Rhyl in North Wales. ${ }^{62}$ Collectively, the thrust of these arguments is that the British seaside became less valued in the late 20th century owing to changes in society.

Due to domestic competition, overseas package holidays and the traditional seaside falling out of fashion, many seaside hotels saw a prolonged drop in occupancy rates. Increased car ownership, in particular, led directly to a higher proportion of day-trippers and therefore a drop in the proportion of overnight visitors to resorts. Eventually, many (former) seaside hotels and guest houses took to housing the unemployed, homeless and mentally disabled to supplement falling visitor numbers and avoid issues of seasonality, as houses of multiple

\footnotetext{
59John Urry, 'Cultural Change and the Seaside Resort', in The Rise and Fall of British Coastal Resorts: Cultural and Economic Perspectives, ed. Shaw and Williams (London: Mansell, 1997), 107-111.

${ }^{60}$ Nigel Morgan and Annette Pritchard, Power and Politics at the Seaside: The Development of Devon's Resorts in the Twentieth Century (Exeter: University of Exeter Press, 1999), 11, 190.

${ }^{61}$ Shields, 'Ritual Pleasures of a Seaside Resort', 73-105.

${ }^{62} \mathrm{Tim}$ Gale, 'Modernism, post Modernism and the decline of British holiday destinations: a case study of Rhyl, North Wales', Tourism Geographies 7 (2005): 86-112.
} 
occupancy. ${ }^{63}$ Poor quality seaside accommodation providers did not much benefit from the growing popularity of short breaks amongst the middle classes.

National government intervention in tourism was generally seen to be ineffective in helping the seaside during this period. Even the 1969 Development of Tourism Act had little impact on accommodation plans at these resorts. The 1950s, 1960s and 1970s can be considered as a period of 'lost opportunities' in which the hugely significant domestic market was allowed to slip away from the seaside resorts without much resistance from national and even local government. ${ }^{64}$ The 1980 s in particular saw resorts, including Morecambe, lose even more of their distinctive attractions and, as a consequence, their holiday-making functions became less significant over time. Many resorts were increasingly becoming centres for retirement and commuters rather than dedicated popular resorts. ${ }^{65}$ As a generalisation resorts experienced a decline in tourism infrastructure and visitor numbers in the last half of the $20^{\text {th }}$ century, although the timing and extent of this decline varied significantly.

From a theoretical stance, much of the discussion surrounding the decline of seaside resorts has focussed on the so-called resort life cycle. In particular, the post-stagnation stages of Butler's Tourism Area Life Cycle (TALC) model has provoked much discussion. ${ }^{66}$ Butler's model predicts stagnation possibly followed by decline or an eventual 'exit from tourism' ${ }^{67}$ Key to this discussion is the fact that Butler's model, whilst a useful descriptive tool, has limitations and various operational problems that mean it cannot easily be applied. ${ }^{68}$ In

\footnotetext{
${ }^{63}$ House of Commons Communities and Local Government Select Committee, Coastal towns: Second report of session, 2006-07, HC 351 (London: The Stationery Office, 2007); Centre for Social Justice, 'Turning The Tide: Social Justice in five seaside towns', http://www.centreforsocialjustice.org.uk/publications/turning-the-tide-socialjustice-in-five-seaside-towns

${ }^{64}$ Demetriadi, 'The golden years', 71.

${ }^{65}$ Walton, The British Seaside, 42.

${ }^{66}$ Richard Butler, 'The Concept of a Tourist Area Cycle of Evolution: Implications of Management Resources', Canadian Geographer 24 (1980): 5-12.

${ }^{67}$ Tom Baum, 'Taking the Exit Route: Extending the Tourism Area Life Cycle Model', Current Issues in Tourism 1 (1988), 170.

${ }^{68}$ Bruce Prideaux, 'The Resort Development Spectrum: The Case of The Gold Coast, Australia', Tourism Geographies 6 (2004): 26-58; Chris Cooper and Stephen Jackson, 'Destination Life Cycle: The Isle of Man Casestudy', Annals of Tourism Research 16 (1989): 737-398.
} 
applying Butler's model to Torbay, Agarwal comments that 'No evidence was found to indicate the occurrence of irreversible decline that the model suggests'. ${ }^{69}$ She also suggests that the later stages of the TALC model are misleading, as it is near impossible to distinguish between the stagnation and post-stagnation phase. It is, therefore, difficult to use the model (or derivatives) in a predictive manner. Agarwal suggested the need for the theoretical reformulation of the post-stagnation' phase.

Generic models and observations regarding the seaside and other destinations provide a useful backdrop to a study of Morecambe's history. They can help to clarify the intertwined and multiplicities factors that led to a gradual decline in the popularity of the British seaside resort. On the other hand, however, they do not explain why some resorts suffered so badly whilst others did not. For example, New Brighton effectively became an ex-resort, Blackpool did not suffer any 'decline' until the 1980s at the earliest and Grange-over-Sands has never moved past the stagnation phase, therefore defying the TALC model altogether. ${ }^{70}$ One shortcoming of the TALC model is that it cannot accommodate the variety and complexity of resorts, which is highlighted by History more than any other discipline. These models and theories often ignore the micro factors, which can be as significant as the macro; resorts need to be dealt with on an individual basis.

In summary, the reasons for resort decline are many and include societal/cultural change, developments in transportation, an explosion of domestic and international competition and the resort life cycle. The features of this decline in popularity include a general deterioration of quality, loss of function and a more negative image. ${ }^{71}$ Cooper outlines the key features that mark the decline of a resort from a supply perspective, such indicators falling under the broad areas of accommodation, employment, transport, environment and

\footnotetext{
${ }^{69}$ Sheela Agarwal, 'The resort cycle and seaside tourism: an assessment of its applicability and validity', Tourism Management 18 (1997), 72.

${ }^{70}$ Walton, The British Seaside, 42.

${ }^{71} \mathrm{Gale}$, 'Modernism, post Modernism', 86-112.
} 
organisation. ${ }^{72}$ Morecambe has seen significant challenges in all of these areas; it suffered a remarkable decline in the second half of the 20th century.

\section{The decline of mass tourism in Morecambe}

The story of Morecambe might have been different had the resort not relied on the Midland railway to provide the flow of Northern proletarian, many from Yorkshire, who were to experience their own economic difficulties. Morecambe's geographical location as the most remote popular Lancashire resort has clearly had an impact on its development and decline. Like many medium-sized resorts, it did not have the reputation or attractions to keep 'pulling them in' when the competition increased in the 1960s. A vicious cycle of decline set in and, even by the 1970s Morecambe, more than most resorts, was something for the aspiring population to mock rather than consume. Morecambe's ebb was so pronounced that its market all but disappeared and the resort was close to experiencing the end of tourism as New Brighton had done. The seeds of Morecambe's problems can, arguably, be traced as far back as the late 1950s. However, by early 1980s it was very clear that the tourism economy of Morecambe had been transformed, 'Morecambe suffered a calamitous fall in visitor spending from $£ 46.6$ million in 1973 to $£ 6.5$ million in 1990, expressed in constant values. Few resorts have suffered such a collapse. ${ }^{93}$ The decline took some time to establish momentum but once this occurred, the results were brutal. In this section, the nature of this collapse is examined, and some resort specific causes are suggested.

Morecambe attracted high numbers of visitors in the 1950s, 1960s and even into the early 1970s. However, as early as the end of the 1950s (after the post-war boom) the attractions/popular entertainment began to dwindle. In 1957, the Royalty Theatre closed for the

\footnotetext{
${ }^{72}$ Cooper, 'Parameters and indicators', 87-92.

${ }^{73}$ John Hassan, The Seaside, Health and The Environment in England and Wales since 1800 (Aldershot: Ashgate, 2003), 254.
} 
winter season for the first time. It was put up for sale, re-opened for a short time but, by the end of the decade, was derelict and destined to become the site of a 1960s shopping centre. In 1958 The Gaumont, with its troubled history, closed for the winter too. Bingham attributes some of this decline to the rising popularity of TV, for one of Morecambe's selling points was its live entertainment - it relied heavily on it and the Winter Gardens theatre was one of the largest in the country outside of London. Other resorts faced similar pressures but perhaps not to the same extent. In 1957 the Winter Gardens tried to respond to this threat by adapting its summer show, it was now 'TV Highlights of 1957'. The Whitehall cinema was the first to close in this period, in 1955. Holiday accommodation was increasingly expected to provide TV for the guests too, along with en-suite bathrooms, which would be rare in Morecambe. ${ }^{74}$ Morecambe was the setting for 'The Entertainer', the 1960 film starring Laurence Olivier. He played Archie Rice, a man of dubious morals whose career as a music hall star was dated and in decline. The atmospheric film reflected this desperation. The music hall and Archie's lodgings appeared unattractive and claustrophobic. Choosing Morecambe as the setting underlines the way in which the resort had become seen by some as seedy by the end of the 1950s. Elborough writes, 'Filmed in 1960 and in Morecambe, the resort comes, by implication at least, to feel as much of a relic on borrowed time as the pitiable Archie Rice'. He also observes how Archie, a representative of the music hall, was seen as worthless by a tourist for never having been 'on the telly', confirming Bingham's observations regarding the impact of television on the resort. ${ }^{75} \mathrm{~T}$.V. alone seems an unlikely cause of such change, but perhaps it contributes to and correlates with it - Walvin suggests that T.V. ownership was significant as one of several indices of rising prosperity (including car ownership) and the cultural change that accompanies it. ${ }^{76}$ The Entertainer was released in 1960 when Morecambe was still busy, so any

\footnotetext{
${ }^{74}$ Bingham, Lost Resort, 263, 270-271, 275.

${ }^{75}$ Travis Elborough, Wish You Were Here: England on Sea (London: Sceptre, 2010), 136.

${ }^{76}$ Walvin, Beside the Seaside, 140.
} 
cultural shift must still have been in the very early stages. ${ }^{77}$ Nevertheless, this period does mark the threshold of a long decline, albeit one that had not yet built momentum. At the time, any decline must have appeared to be a temporary blip for a seaside economy that had experienced significant slumps in its past.

The tourism trade continued to support a variety of businesses throughout the 1960s but this was not as much a period of rapid expansion and optimism as the early 1950s had been. Heysham Head amusement park closed in 1964, in 'Scotch Week' 1968 'vacancies' signs were noticed all along Morecambe promenade for the first time and the number of boarding-houses fell from 1300 in 1956 to 927 in $1960 .{ }^{78}$ Census information reveals that the population of Morecambe stagnated at around 41,000 from 1961 onwards. In the 1960's to some extent, but more noticeably in the 1970s, Morecambe was losing hotels, attractions and credibility as a desirable destination whilst gaining self-catering accommodation and retirement homes.

Furthermore, Morecambe was literally becoming a joke, as it provided the material for comics. TV comedian, Colin Crompton described it as a cemetery with lights, they don't bury their dead but stand them up is bus shelters - the most exciting thing to do is watch traffic lights change colour. ${ }^{79}$ Morecambe's lack of entertainment and aging population would be a target of his comic routine through the 1970s. The Costa Geriatrica had not only become deeply unfashionable but was undergoing a public relations disaster which was likely to do untold damage for years; this in an industry where a positive place image is essential. ${ }^{80} \mathrm{Such}$ placeism was not limited to this time period or to comedy. In the following decade, Paul Theroux recalled his journey around the coast of Britain in a popular travelogue; he saved his most

\footnotetext{
${ }^{77}$ Urry, 'Cultural Change and the Seaside Resort', 107-111.

${ }^{78}$ Heysham Heritage Association, 'Heysham Head', http://www.heyshamheritage.org.uk/html/heyshamhead.html; Bingham, Lost Resort, Chapter 6.

79John Finch, Granada Television - The First Generation (Manchester: Manchester University Press, 2003 ), 174.

${ }^{80}$ David Jarratt, Chris Phelan, Jenny Wain and Sarah Dale, 'Developing a sense of place toolkit: Identifying destination uniqueness', Tourism and Hospitality Research 19 (2018),

https://doi.org/10.1177/1467358418768678
} 
derisory comments for Morecambe - he thought day-trippers must burst into tears upon arrival. $^{81}$

Jokes about Morecambe from Crompton and others were met with laughs because the public knew how far the once fashionable resort had fallen from grace. By the mid-1970s, visitor entertainment in Morecambe consisted mostly of bingo or amusement arcades and the only new addition was a bowling alley which lasted eighteen months, before becoming a bingo hall. The Alhambra was closed to the public, re-opened with a drag act show but burnt to the ground in 1970, never to be rebuilt. The Swimming Stadium, a major attraction, closed in 1975 after 39 years which were beset by structural problems. ${ }^{82}$ The Morecambe Dome was built in its place in 1979 but the venue was never really successful and was seen to represent underinvestment and a lack of confidence in the resort. The well-known Winter Gardens theatre (dating back to 1897) closed to the public in $1977 .{ }^{83}$ The West End Pier was storm demolished in 1978 following storm damage the previous year, leaving only the Central Pier. ${ }^{84}$ Morecambe Pleasure Land (later Frontier Land theme park) continued to operate as a significant attraction for the resort but otherwise most attractions found it difficult to survive past the mid-1970s.

The loss of these major entertainment venues in the mid-late 1970s left fewer reasons to visit. This is summed up in these verbatim excerpts from an interview with a former resident, ... at the Winter Gardens, they used to have top acts... and I think it was ' 77 when the west end pier went, so I mean that sort of thing has changed. And I think it was sort of almost, heralded the demise of the the seaside resort of Morecambe because I mean the pier or both piers were a big draw.

...I mean I certainly remember there were, what, four cinemas when I was growing up in Morecambe. Then going back perhaps beyond my early years, there would be, I think it was...was it four or five theatres?

...the biggest change is the lack now of facilities, for holidaymakers. And is this why a lot of people you know, pass the place by now and will go to Blackpool because there are still the three piers, there's the towers, whatever - there's entertainment there that you know... Whereas if you come to Morecambe, you

\footnotetext{
${ }^{81}$ Paul Theroux, The Kingdom by The Sea: A Journey Around the Coast of Great Britain (London: Penguin, 1984), 215.

82Janet Smith, Liquid assets: The Lidos and Open Air Swimming Pools of Britain (Swindon; English Heritage, 2005), 86, 126.

${ }^{83}$ Historic England, 'The Winter Gardens', http://www.pastscape.org.uk/hob.aspx?hob id=1152901; Morecambe Winter Gardens, 'History', www. morecambewintergardens.co.uk

${ }^{84}$ National Piers Society, 'Lost Piers', https://www.piers.org.uk/pier/morecambe-west-end-pier/.
} 
know, by 9 o'clock everything is shut up. You know, I know I'm exaggerating but I mean that is at least how it appears. There, there's, there's nothing... ${ }^{85}$

Another challenge for the resort, in the face of declining numbers, was the modernisation of the accommodation offering. An e-mail exchange with a former hotel owner offers an

illuminating account of Morecambe in that period:

I was the owner-proprietor of the **** Hotel on the seafront from 1972 to 1977 . The hotel at that time had 14 bedrooms one communal bathroom and two shared toilets taking up to 34 guests. We made much in our advertising that the bedrooms all had hot and cold basins and that the beds were sprung interior mattresses. Meaning that we had replaced the flock mattresses and iron framed beds. The price in the early 70s to stay at the hotel ranged from 9 Guineas low season to 11 Guineans high season (£9.45p to $£ 11.55 \mathrm{p}$ ) for a week full board. Most guest houses offered full board as holidaymakers demanded three meals a day.

During this time I became a member of the Morecambe Hotel and Caterers Committee. This organisation was a very influential force in Morecambe second only to the Town Council and committee meetings were recorded and reported in the local press. Most of the committee were of the 'old school' and were opposed to change or modernisation. For example, there was a long protracted debate on whether the committee should insist that members should supply towels in the bedrooms. The more forward-thinking members were suggesting installing on-suite bathrooms and upgrading facilities to counter the threat from foreign holidays but this investment was beyond comprehension, especially when it was revealed that the president of the committee was only charging $£ 6.00$ per week for full-board! ${ }^{86}$

In short, much of the resorts private sector was no longer meeting the expectations of modern tourists in terms of entertainment or accommodation - the shows were disappearing and the accommodation was of poor quality and old fashioned. The mid-1970s was when the situation worsened and the resort entered a vicious cycle of decline. One event which correlated with this, was the merger of Morecambe and Lancaster councils (into Lancaster City Council) in 1974. Morecambrians tend to believe that decisions made thereafter often prioritized Lancaster or, at least, that decisions were no longer been made by a council with tourism in the front of its mind - for example the lack of well-funded / effective destination marketing. An excerpt from the aforementioned interview with a local resident demonstrates this, 'I know my Dad...as a resident there for many years, 50 years in fact, he used to say that the problems with Morecambe started in 1974 with the reorganisation of local government'. As the retail offer of

\footnotetext{
${ }^{85}$ Interview with a former resident who lived in the resort between 1950 and 1984 after moving there as a boy and whose family were involved with the towns entertainment industry. The 58 minute long interview was conducted by the author, in confidentiality, in July 2011.

${ }^{86} \mathrm{E}$-mail message to the author $24^{\text {th }}$ December, 2012. Treated as confidential.
} 
neighbouring Lancaster grew in the 1980s, so did resentment within the resort. So much so, that the Morecambe Bay Independents political party pushed for independence from Lancaster City Council, without success. ${ }^{87}$ Even the most generous of observers would have to agree that some of the decisions made by the council through the 1980s and into the 1990s were questionable; Blobbygate and the loss of Frontier Land in particular - these are explored subsequently, but first the wider context is examined.

The 1980s was, perhaps, the worst decade for tourism in Morecambe. The Dome hosted the last Miss Great Britain competition, so closely associated with the resort for three decades. The one remaining pier closed its doors in 1986 and was finally demolished six years later. ${ }^{88}$ 1990 the Oceanarium, Marine Land, closed after 26 years, most of which were marked by financial difficulty. ${ }^{89}$ Not only had Morecambe lost all but one of its major attractions (Frontier Land) but it could not even support a cinema as neighbouring Lancaster and most other English towns did. Organised entertainment consisted of bowling and bingo.

The number of boarding houses dropped from 927 in 1960, to 772 in 1980 to just 123 in 1990. ${ }^{90}$ The Grand Hotel was turned into flats but eventually demolished in 1989 . The Grosvenor Hotel was housing DHSS (unemployment benefit) claimants but closed in 1987. The art-deco Midland Hotel survived but was not operating as a good quality hotel as it once did, and at one time there were even plans to turn it into a University Hall of Residence. ${ }^{91}$ In the following decades, the resort did retain two fully functioning larger hotels in the form of the Broadway and Strathmore. These were increasingly reliant upon an ageing market, often supplied through coach tour operators such as Wallace Arnold.

\footnotetext{
${ }^{87}$ Phillip Cooke, Localities: The Changing Face of Urban Britain (London: Routledge, 1989), 153.

${ }^{88}$ National Piers Society, 'Lost Piers', https://www.piers.org.uk/pier/morecambe-central-pier/

${ }^{89}$ John Dineley, 'Marine Land Morecambe', UK Dolphinaria Blog, posted $20^{\text {th }}$ July 2015, http://ukdolphinaria.blogspot.com/2015/07/marineland-morecambe-1964-1990.html

${ }^{90}$ Bingham, Lost Resort, 286.

${ }^{91}$ Guise and Brook, The Midland Hotel.
} 
Unemployment levels in some Morecambe wards were approaching 50\% in the 1980s, one of the highest rates in the country. The urban North no longer sent its holidaymakers but it's unemployed to the Costa del Dole. Local hoteliers advertised for DHSS tenants in the local Blackburn and Liverpool papers. The link between less prosperous seaside resorts, such as Morecambe, and a range of social problems, such as low levels of educational attainment, poor health and substance abuse, persist. Levels of socio-economic disadvantage and exclusion that one might expect in the inner cities, can be found in numerous seaside resorts across the country today. ${ }^{92}$ The focus of this article is on tourism rather than social problems facing residents, but of course, social problems impact upon the visitor experience, media coverage and place image. ${ }^{93}$

In the early 1980s, neighbouring Heysham would become important for the extraction of natural gas from Morecambe Bay and because of the nuclear power station that had just become operational. The siting of the power station would do nothing to attract tourists but construction workers who had worked on the site since 1970 had proven a useful source of income for local hoteliers. So much so that, arguably, they became reliant on the workers and delayed investing in their businesses and improving their offerings. The West End of Morecambe, once favoured as the place to reside in the town, was closer to the new industry of Heysham and now had high rates of unemployment and poverty.

Like those involved with constructing Heysham's nuclear power station, Lancaster University students also eventually left the surplus of accommodation of Morecambe behind. ${ }^{94}$

\footnotetext{
${ }^{92}$ Sheela Agarwal, Steven Jakes, Stephen Essex, Stephen Page and Martin Mowforth, 'Disadvantage in English seaside resorts: A typology of deprived Neighbourhoods', Tourism Management 69 (2018): 440-459.

${ }^{93}$ For example - Olivia Rudgard, 'Decline of the British seaside resort as coastal communities plagued by heroin', The Daily Telegraph, $4^{\text {th }}$ April, 2018, https://www.telegraph.co.uk/news/2018/04/04/decline-british-seasideresort-coastal-communities-plagued-heroin/ ${ }^{94} \mathrm{John}$ Harris and John Domokos, 'Anywhere but Westminster, Morecambe: The seaside town that cuts brought to a standstill', The Guardian on-line, $21^{\text {st }}$ July, 2011, http://www.guardian.co.uk/commentisfree/video/2011/jul/21/morecambe-cuts-video
} 
Today the University students are much more likely to live in Lancaster itself, which is now more prosperous, or in new purpose-built accommodation on campus.

Hassan points out that the level of environmental pollution in Morecambe Bay was very high from the 1960s onwards. He observed that through the 1980s and especially in the 1990s, the media regularly reported nuclear contamination in the Irish Sea, the problems with Morecambe/Heysham sewage disposal and the fact that Morecambe had the country's second dirtiest beach. The resort's, 'greatest asset, the beautiful Morecambe Bay, began to be portrayed as a polluted sink'. In 1991 and following a Consumer's Association study, the BBC even raised the possibility that a bather could contract AIDS from bathing in Morecambe Bay. Such coverage over the years amounted to a public relations disaster. ${ }^{95}$

The only academic article to consider 1990s tourism in Morecambe, argued that an increased synergy between leisure and tourism / local and tourist needs and provision would lead to a more effective rejuvenation and regeneration of the destination. ${ }^{96}$ This research points out that this was most certainly not the case in the Mr. Blobby Crinkley Bottom Theme Park fiasco (known locally as Blobbygate), which was associated with the television celebrity Noel Edmonds. The doomed theme park threatened to rob Morecambrians of their local park, lasted only months and left behind substantial debt and litigation in 1994. With hindsight, it is clear that the project was ill-conceived, unsustainable and smacked of desperation on the part of the council. ${ }^{97}$ Morecambe's swimming pool, Bubbles, closed soon after Blobbygate. The association between the closure of a tourist attraction and a 'disagreement' with the council was to be repeated as the new millennium came in.

The year 2000 was marked by the closure of Morecambe's last remaining attraction of note, Frontier Land. This small theme park had been operating in some form for over ninety

\footnotetext{
${ }^{95}$ Hassan, The Seaside, Health and The Environment, 256-257.

${ }^{96}$ Christine Williams, Davina Chaplin and Martine Middleton, 'A seaside resort's journey from decline to rejuvenation via leisure and tourism consumption convergence', WHATT Journal 2 (2001): 19-32. ${ }^{97}$ Ibid.
} 
years but its Western theme and new name dated back to 1987. It had developed rapidly in the 1940s when bought by Mr. L. Thompson of the Blackpool Pleasure Beach dynasty. The Thompson family were to run the site until its closure. In the 1970s the 'Morecambe Pleasure Park' had 25 major rides and 10 for children. In 1980 'Fun City', as the park was then called, came into conflict with the council over planning issues surrounding a very large Ferris wheel which was in operation. Mr. G. Thompson was to prove that the structure was indeed moveable (and therefore did not require planning permission) when it was shipped to the USA. It seems that the dispute with the council may well have cost Morecambe its new landmark. The council had been responding to complaints from locals that the wheel had been intrusive and spoilt their view.

In the late 1980s, Frontier Land included popular rides such as the Fun House which burnt down in 1987, The Texas Tornado and the Wild Mouse Roller Coaster - both of which were put up for sale in 1999. In 1998, Mr. G. Thompson threatened to pull out of Morecambe altogether if the council, which was in the process of closing Bubbles indoor Water Park, did not display more commitment to tourism in the town. The future of Frontier Land must have seemed precarious at this point but then the Silver Mines Ride and other smaller attractions were burnt down in an arson attack in 2000, which meant the end. ${ }^{98}$

While one is not privy to all of the information relevant to the decision to pull out of Morecambe, it seems that Thompson and the council did not have a good working relationship and this contributed to problems facing the attraction. The only remaining purpose-built tourist attraction of note had gone the way of so many other attractions. Most of the site, situated on the seafront, would remain derelict until the present day.

${ }^{98}$ The Visitor, 'End of the Ride for Frontierland', 22/08/07, https://www.thevisitor.co.uk/news/end-of-the-ridefor-frontierland-1-1207493. 
Meanwhile, Morecambe's reputation in popular culture and the media continued to suffer; in 2003 it was listed as one of Britain's ten most 'Crap Towns' by the Idler magazine an article that proved so popular, that it led to a book of the same name. ${ }^{99}$ Just as in the 1970 s, Morecambe (now the third crappest town in Britain) was the butt of jokes rather than the aspirational destination it had been in the inter-war period.

In summary, the post-war years saw a significant spike in visitor numbers to Morecambe and the seaside more generally. Many resorts were to experience a subsequent downturn in their fortunes, but for Morecambe this downturn was early and extreme. The 1960s saw a slow but steady decline in the number of tourism businesses and by the late 1970s, the majority of tourist attractions had been forced into closure and accommodation stock was dropping very rapidly. The stripping of the tourism infrastructure and reputation continued through the 1980s and into the 1990s. Blobbygate took its toll, and in 2000 the last man-made attraction of note closed. Morecambe had failed to re-invent itself as some southern resorts had done and it could not compete against the ever popular Blackpool. ${ }^{100}$ However, the 1990s were notable because they marked the start of an attempt to regenerate the failing resort and offered hope.

\section{Regeneration in Morecambe}

A full account of the regeneration of the town is outside the scope of this article, nevertheless, a summary of some of the main developments are offered here. Morecambe's Tern Project commenced in 1994 and was completed by the end of the decade. It combined essential improvements to the coastal defences following earlier floods and a new promenade, which incorporated public art featuring a bird-life theme and a statue of the comic Eric Morecambe.

\footnotetext{
${ }^{99}$ Elborough, Wish You Were Here, 4; Sam Jordison and Dan Kieran, The Idler Book of Crap Towns: The Fifty Worst Places to Live in the UK (London: Boxtree, 2003).

${ }^{100}$ Hassan, The seaside, Health and The Environment, 254-259.
} 
In total $£ 26$ million of government funds was spent; enquiries at Morecambe Visitor Centre rose from 73,529 in 1994 to 146, 516 in 2005 and the Tern Project has helped to sustain the numbers of day-visits. ${ }^{101}$ The once derelict Midland Hotel was redeveloped by Urban Splash and finally opened in 2008; this process became a symbol of successful regeneration and therefore of a potentially brighter future. This architecturally significant hotel attracted a good deal of positive media coverage and featured in the BBCs popular 'Coast' television programme. ${ }^{102}$ Plans were proposed by Urban Splash for the redevelopment of a fun fair site, next to the Midland on the promenade, but these were rejected by Lancaster City Council in 2013. It has been claimed the private sector is struggling to contribute to the recent rejuvenation in Morecambe under difficult economic circumstances. ${ }^{103}$ However, Morecambe BID (Business Improvement District) has had some success keeping the momentum of regeneration, which was much needed. For example, they were involved, along with Lancaster City Council and others, in a proposal for a new Eden Project in the resort - Eden North. ${ }^{104}$ This would be the first major tourist attraction to open for many years. The Eden Project has stated that the project 'will be designed to help the regeneration of the area socially, economically and environmentally' ${ }^{105}$ In addition, a new link road has connected Morecambe to the motorway network since 2016 and the local beaches are cleaner then they have been for years, largely due to EU directives. ${ }^{106}$ There are also various housing and social regeneration projects in the town,

\footnotetext{
${ }^{101} \mathrm{Jim}$ Trotman, 'Morecambe - Tourism Trends and Redevelopment' (Unpublished Lancaster City Council briefing report, June 2007).

${ }^{102}$ Coast - Southport to Whitehaven (episode 3, series 3). Directed and produced by Richard Sharman. London: BBC2, 2007. Also see - Jenny Steele, 'The Midland Hotel, Morecambe', Looking Back Moving Forwards Blog, posted $23^{\text {rd }}$ May 2015, https://lookingbackmovingforward2014.wordpress.com/2015/05/23/the-midland-hotelmorecambe/

${ }^{103}$ Harris and Domokos, 'Anywhere but Westminster'.

${ }^{104}$ BBC, 'Eden Project: Proposal to bring attraction to Morecambe' (20 April 2018), https://www.bbc.co.uk/news/uk-england-lancashire-43836494.

105 Eden Project, 'New Vision for Morecambe's Eden project revealed' (22 November 2018), https:// www.edenproject.com/media/2018/11/new-vision-morecambes-eden-project-revealed ${ }^{106}$ Damian Carrington, 'What has the EU ever done for my beach?', The Guardian, $9^{\text {th }}$ June, 2016, https://www.theguardian.com/environment/2016/jun/09/what-has-the-eu-ever-done-for-my-beach.
} 
which still has significant socio-economic challenges. The $21^{\text {st }}$ century has seen a steady increase in visitor numbers to Morecambe. ${ }^{107}$

Over the last decade or two, the English seaside resort has had a renaissance. Seaside towns around the country have seen numbers swell. Reasons for this growth include recent changes to the value of the pound brought on by Brexit and a growing demand for traditional holidays fit for modern consumers. ${ }^{108}$ In 2015 , the seaside accounted for $37 \%$ of all British holiday nights - more than other location types. ${ }^{109}$ Visitor numbers are increasing and traditional seaside resorts, including Morecambe, have become more fashionable. Cultural shifts now appear to be benefitting the seaside. Over the last ten years, Travel Lodge has invested in 55 new seaside hotels (including one in Morecambe) and demand for Butlins seaside holidays has soared. ${ }^{110}$ Dreamland, Margate, has re-opened as a vintage amusement park and Blackpool will soon host a new museum celebrating the history of tourism to the resort. The designer Wayne Hemingway argues that there is a movement amongst young people to rediscover the coast and this is facilitated through a growing programme of coastal events. ${ }^{111}$ Examples include Coastival in Scarborough and The Great Seaside Vintage Fair in Whitby. Indeed, Morecambe's nostalgia-fuelled Vintage by The Sea Festival attracted 40,000 visitors in 2017 , compared with 6,000 only three years earlier. ${ }^{112}$ These figures may not be the 100,000

\footnotetext{
${ }^{107}$ Lancaster City Council, 'Morecambe STEAM Report 2007', http://www.lancaster.gov.uk/GetAsset.aspx?id=fAAyADQAMAA5AHwAfABGAGEAbABzAGUAfAB8ADAAfAA1, (accessed 2nd November 2012); Lancaster City Council, 'Morecambe STEAM Report 2010', http://www.lancaster.gov.uk/tourism/destination-performance/, (accessed 17th November 2012). These figures estimate 3.6 million visitors in 2010 in comparison with 2.4 million in 2007.

${ }^{108}$ Joshua Chaffin, 'Butlins woos cash-strapped vacationers in Brexit Britain', Financial Times, 26 ${ }^{\text {th }}$ August, 2017, https://www.ft.com/content/176447ee-8986-11e7-bf50-e1c239b45787.

${ }^{109}$ Visit Britain, 'The GB Tourist: Statistics 2015', https://www.visitbritain.org/sites/default/files/vbcorporate/Documents-Library/documents/England-documents/gb tourist report 2015.pdf Accessed 24/07/2018, 81, 86. 72.6 million visitor nights were spent at seaside locations in 2015, from a total of 194.6 million. The 2 nd most visited category was countryside/village with 47.7 million, followed by city/large town and small town categories - each of which attracted under 40 million visitor nights. The seaside also attracted $£ 4.4$ billion of visitor spend in 2015, more than the other location category.

${ }^{110} \mathrm{BBC}$, 'Travel Lodge invests in the seaside', http://news.bbc.co.uk/1/hi/business/7517153.stm; Chaffin, 'Butlins woos cash-strapped vacationers in Brexit Britain'.

${ }^{111} \mathrm{BBC}$ Breakfast, Interview with Wayne Hemmingway, BBC1, 7th September, 2017.

${ }^{112}$ Deco Publique, 'Vintage by the sea', http://www.decopublique.co.uk/vintage-by-the-sea-.1
} 
reported at the 1949 illumination switch-on event, but they are healthy and growing. The roots of recovery, albeit a partial recovery, of Morecambe's visitor economy are now established.

\section{Conclusion}

Morecambe's early to mid-20th century boom seems as remarkable as its rapid decline; the contrast is stark. Its late development, medium size (too small to compete with Blackpool, too big to be exclusive), physical isolation, fierce competition, poor reputation, issues of governance and a range of other factors discussed in this article, meant that the resort was plagued by a more severe decline in visitor numbers and infrastructure than most English resorts. However, Morecambe did not become an ex-resort. Whilst the 1980s were bleak, the town maintained a depleted but loyal older following and held a nostalgic appeal. ${ }^{113}$ Its history is not a straightforward one of flow and ebb in the face of cheap flights, there were a variety of macro and micro factors at play. Indeed the resort, faced a significant downturn at the start of the 20th century, albeit a much shorter one than it would start to experience several decades later. Furthermore, not all developments were entirely negative. For example the nearby nuclear power station, which played a role in the decline of tourism, offers many well-paid jobs in the region. Also, outlying areas have seen the development of a buoyant caravan economy, which supply more visitors to the resort than the reduced number of B\&Bs might suggest. ${ }^{114}$

There is evidence of regeneration and renewed confidence in the resort recently. ${ }^{115}$ Morecambe should not aim to recapture its short-lived boom years, but perhaps develop a sustainable and diverse visitor economy. The best way to achieve this will be contested, but there are certain attributes of this resort which have remained from its earliest days and are

\footnotetext{
${ }^{113}$ David Jarratt and Sean Gammon, 'We had the most wonderful times: seaside nostalgia at a British resort', Tourism Recreation Research, 41(2016): 123-133.

${ }^{114}$ Demetriadi, 'The golden years', 61-63.

115 House of Lords Select Committee, 'The future of seaside towns' (2019), 16, https://publications.parliament.uk/pa/ld201719/Idselect/ldseaside/320/320.pdf
} 
perhaps highlighted because so much of the touristic infrastructure has disappeared. Indeed, this cycle of infrastructure boom and bust (which is reminiscent of the TALC model ${ }^{116}$ ) has done nothing to diminish the long-standing draw of the coast and the bay, as this guide from 1899 testifies,

'...there is nothing strictly ancient about Morecambe except the land and the sea, and there is no doubt that these must ever remain the chief attractions of the place, whatever accessories may be provided by the authorities and others'. ${ }^{117}$

The resort's main attraction since industrialisation, a connection to the sea/nature, remains and might be buoyed by recent improvements to the quality of the coastal environment. ${ }^{118}$ With this in mind and in light of recent developments, especially the Eden North proposal, one can afford to be optimistic about the future of the resort. This optimism should be tempered by caution however, for the interplay of local and global shifts which have shaped the resort's history, and will shape its future, are dynamic. Walvin's observation that since the war, resorts may thrive in 'inverse proportion to national prosperity' does appear credible; the growth in staycation after the 2008 slump and Brexit influenced exchange rates, along with a sense of nostalgia, appear to have boosted the fortunes of the seaside resort. ${ }^{119}$ The implication is that the future is uncertain, as the economy adjusts. However, the history of the traditional British seaside resort is one of conspicuous adaptation and resilience.

It is remarkable that the cotton mills have closed, the age of railway has given way to the age of the car and we now aspire to visit city centres rather than to escape their once polluted environments, yet these seaside towns of the industrial revolution survive. The English seaside resort appears to be an abiding social construction which is capable of

\footnotetext{
${ }^{116}$ Butler, 'The Concept of a Tourist Area Cycle of Evolution'.

${ }^{117}$ Johnsons Guides for the People, A new guide to Morecambe, 6.

${ }^{118}$ David Jarratt, 'Seasideness: sense of place at a seaside resort', in Landscapes of Leisure: Space, Place and Identities, ed. Sean Gammon and Sam Elkington (London: Palgrave, 2015): 147-163.

${ }^{119}$ Walvin, Beside the Seaside, 138.
} 
withstanding a variety of interwoven micro and macro factors which threaten its survival, and there is no better example than the chequered history of Morecambe. 